\title{
Approaches Regarding Red Mud Valorization for a Green Future and Sustainable Environment
}

\begin{abstract}
ADRIANA CUCIUREANU*, GEORGIANA CERNICA, BOGDAN ADRIAN STANESCU, IOANA ALEXANDRA IONESCU

National Research and Development Institute for Industrial Ecology - ECOIND, 71-73 Drumul Podu Dambovitei Str., 060652 Bucharest, Romania

Today the red mud generated from alumina production is a resource, a material that can be valorized, an opportunity. The current practice in waste management in some parts of the planet has to be revised. We need to change technologies and become more aware and thoughtful on our footprint on Earth. Red mud is the main waste generated from the bauxite Bayer process. Having a complex composition with predominantly $\mathrm{Al}_{2} \mathrm{O}_{3}$ (14-27\%), $\mathrm{Fe}_{2} \mathrm{O}_{3}$ (19-56\%) contents, viable solutions were sought for the reuse of the red mud. A number of applications have resulted in the recovery of metallic components, chemical industry, and building materials industry. A field of red mud applicability, which has enabled the development of innovative and sustainable techniques, is that of the environment. The paper presents the results of the researches carried out in order to valorize the red mud in the treatment of two categories of wastewater: phosphates waters and mine waters. The influence of the experimental parameters on the pollutant removal efficiencies in these wastewaters is highlighted.
\end{abstract}

Keywords: environment, red mud, SEM, wastewaters

Red mud, is the major solid waste produced during alkaline leaching of bauxite in the Bayer processes. For every tone of alumina produced, roughly 1-2 tonesof red mud residue are generated [1-3]. The increasing demand of alumina generates more red mud which is disposed on large areas. Due to the alkaline nature (highly caustic with a pH of 10.5-12.5) and large amount (worldwide generation is 70-90 million tones every year) of red mud which must be disposed year by year it causes a serious health and environmental problem. [4-10]. There is a scarcity of available lands to store them [11]. The environmental risk is due to the presence of major components ( $\mathrm{Si}, \mathrm{Al}, \mathrm{Fe}, \mathrm{Ca}, \mathrm{Na}$, Ti oxides and hydroxides) and minor components $(\mathrm{K}, \mathrm{Cr}, \mathrm{V}, \mathrm{Ba}, \mathrm{Cu}, \mathrm{Mn}, \mathrm{Pb}, \mathrm{Zn}, \mathrm{P}, \mathrm{F}, \mathrm{S}, \mathrm{As})$. The chemical analysis of different types of the red mud shows the following contents: $\mathrm{Al}_{2} \mathrm{O}_{3}(14-27 \%), \mathrm{Fe}_{2} \mathrm{O}_{3}(19-56 \%), \mathrm{TiO}_{2}$ (1.9-21\%), $\mathrm{Na}_{2} \mathrm{O}(0.4-12 \%), \mathrm{SiO}_{2}(1.3-21 \%), \mathrm{CaO}(0.2-12 \%)$ [12-16]. These fine particles of oxides and hydroxides are responsible for the red mud high surface reactivity [17-19]. Because of these characteristics red mud has been the subject of many investigations finding opportunities for reuse, capitalization instead of storage. Figure 1 presents the main potential applications of red mud [20].

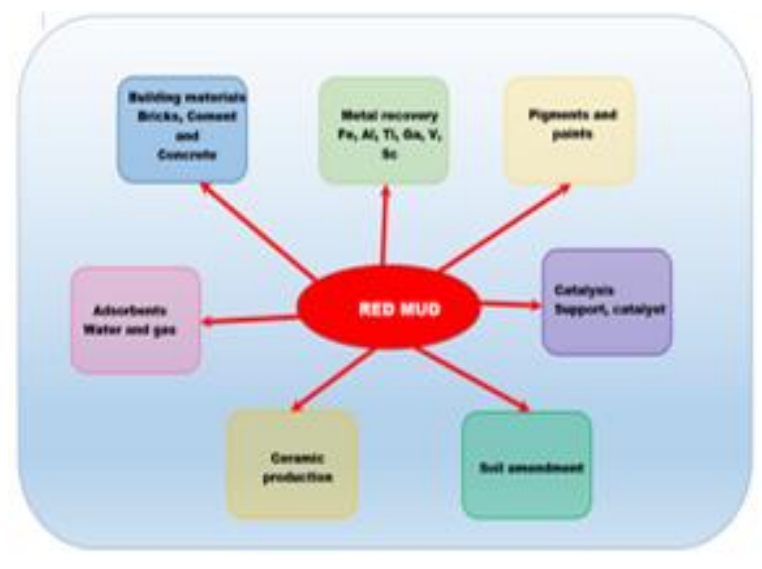

Fig.1. Potential applications of red mud

*email:adriana.cuciureanu@incdecoind.ro, Phone: 02141003 77/246 
A field of red mud applicability, which has enabled the development of innovative and sustainable techniques, is that prothe environment. Wastewater containing heavy metals, metalloid ions, inorganic anions such phosphate, nitrate, fluoride, as well as organics including dyes, phenolic compounds have been treated using different types of materials with good adsorption properties. Wastewater treatment technologies using commonly adsorbents that are expensive [20]. In the recent years some directions on developing low-cost adsorbents from industrial and agricultural wastes have been extensively studied [21-24].

The mineral and chemical composition of red mud makes it a potential sorbent material [25-26].

Recent research has focused on developing red mud into an agent for treating wastewaters, with potential benefits for both the industry and the environment [11]. It can be used as a replacement of other adsorbents therefore saving natural resources [20].

Because of its composition the red can be used as a mixture of adsorbent and flocculation the same time. This it is the basic advantage on wastewater treatment and represents its versatile application [11].

Red mud applications for the removal of different type of pollutants such as phosphates from various industrial wastewaters and heavy metals from mine waters are discussed in this paper.

The aim of these researches has been the possibility of valorization the red mud in the treatment of two categories of wastewaters with a major impact on the environment: water containing phosphates if that are discharged into surface water bodies may lead to eutrophication, rapid deterioration of water quality and mine water containing heavy metals and a strong acidic character which may lead toxicity to aquatic organisms, even at low concentration.

\section{Experimental part}

Materials and methods

Materials

The red mud sample was subjected to a first stage of moisture removal by thin layer drying in plastic trays at the environment temperature $25-30^{\circ} \mathrm{C}$, for 72 hours; this was done in a specially designed chamber for sample drying, provided with ventilation for air circulation and external exhaust of excess humidity. Afterwards a crushing and passing on the sieve with the size $\Phi=500 \mu \mathrm{m}$ was made to obtain the fraction that was used further in the experimental research (RM). A part of the red mud processed (RM) was then subjected to the heat treatment process, in a furnace, at $800^{\circ} \mathrm{C}$, for 2 hours $(\mathrm{RMH})$.

The wastewater used in these experiments were collected from different sources, paper making and knitewear production plants (wastewaters with phosphorous contents), respectively from an abandoned mine (mine water with heavy metals).

\section{Characterization}

The two prepared red mud samples were characterized to physical properties, chemical composition, microstructure and surface morphology. The $\mathrm{pH}$ was measured using a WTW 9430 multiparameter. The specific surface area was measured by Mastersizer 2000 equipment. The quantitative elemental composition was determined by X-ray fluorescence (XRF) using ED-XRF Rigacu. The results presented in table 1 show the red mud samples main constituents and the physical properties (before treatment RM and after heat treatment RMH).

Table 1

THE MAIN CHARACTERISTICS OF THE TWO RED MUD SAMPLES

\begin{tabular}{|llll|}
\hline Parameters & UM & RM & RMH \\
\hline $\mathrm{pH}$ & Unit $\mathrm{pH}$ & 10.9 & 12.1 \\
\hline Dry matter & $\%$ & 98.5 & 99.2 \\
\hline $\mathrm{Specific} \mathrm{surface}$ & $\mathrm{m}^{2} / \mathrm{g}$ & 12.4 & 12.6 \\
\hline $\mathrm{Al}_{2} \mathrm{O}_{3}$ & $\%$ & 25.6 & 26.2 \\
\hline $\mathrm{SiO}_{2}$ & $\%$ & 13.7 & 13.6 \\
\hline $\mathrm{Fe}_{2} \mathrm{O}_{3}$ & $\%$ & 39.8 & 39.7 \\
\hline $\mathrm{TiO} 2$ & $\%$ & 2.38 & 2.2 \\
\hline $\mathrm{CaO}$ & $\%$ & 6.3 & 6.1 \\
\hline $\mathrm{Na} 2$ & $\%$ & 10.07 & 9.8 \\
\hline $\mathrm{MnO}_{2} \mathrm{O}$ & 0.04 & 0.04 \\
\hline $\mathrm{V}_{2} \mathrm{O}_{5}$ & $\%$ & 0.17 & 0.19 \\
\hline $\mathrm{Cr}_{2} \mathrm{O}_{3}$ & $\%$ & 0.15 & 0.16 \\
\hline
\end{tabular}



$3)$.

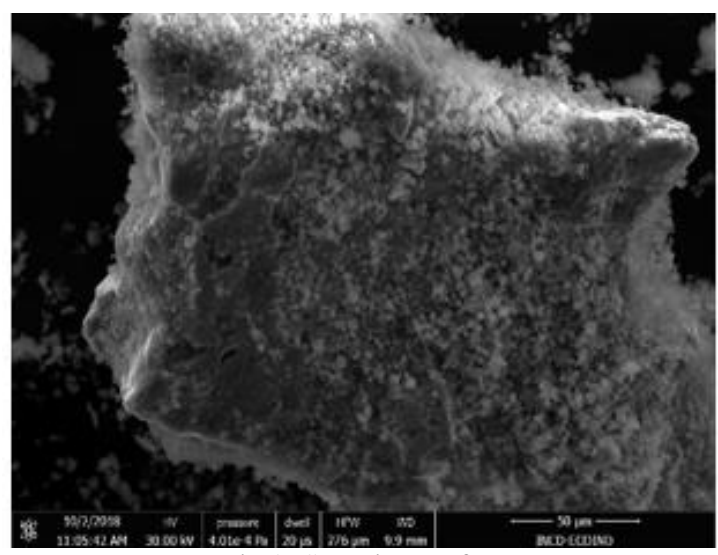

Fig.2. SEM image for RM

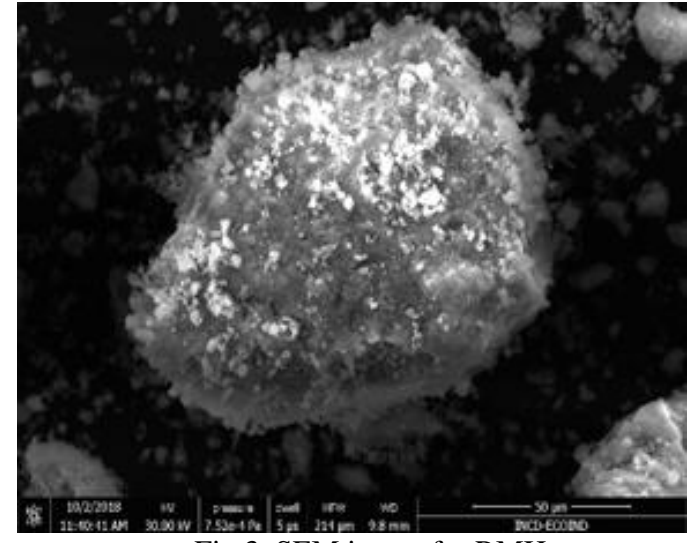

Fig.3. SEM image for RMH

The wastewater collected from paper making planthas the following composition: $\mathrm{COD}=170 \mathrm{mgO} / \mathrm{L}$, phosphates $=$ $15.2 \mathrm{mg} / \mathrm{L}, p \mathrm{H}=7.6$, chlorides $=196 \mathrm{mg} / \mathrm{L}$ and the wastewater collected from knitewear production plants has the following composition: $\mathrm{COD}=220 \mathrm{mgO}_{2} / \mathrm{L}$, phosphates $=13.2 \mathrm{mg} / \mathrm{L}, p \mathrm{H}=6.3$, chlorides $=1300 \mathrm{mg} / \mathrm{L}$. The mine water experimental composition was: $p \mathrm{H}=2.6, \mathrm{Ni}=3.2 \mathrm{mg} / \mathrm{L}, \mathrm{Cd}=1.7 \mathrm{mg} / \mathrm{L}, \mathrm{Cu}=4.8 \mathrm{mg} / \mathrm{L}, \mathrm{Zn}=278.8 \mathrm{mg} / \mathrm{L}, \mathrm{As}=0.91 \mathrm{mg} / \mathrm{L}, \mathrm{Mn}=171.2 \mathrm{mg} / \mathrm{L}$.

\section{Experimental part}

In order to determine the phosphate removal capacity or the metals removal capacity batch experiments were conducted. The effects of the type and the dose red mud samples to the efficiency were studied. The experimental procedure was as follows: the red mud samples were placed in Erlenmeyer flasks with the different wastewaters and there was stirred at 100 $\mathrm{rpm}$, at room temperature, for $16 \mathrm{~h}$. Different amount of red mud were used $(0.5-20 \mathrm{~g} / \mathrm{L})$. After the selected contact time has expired, vacuum separation of the liquid phase sludge through a $0.45 \mu \mathrm{m}$ cellulose membrane has been performed.The liquid phase was analyzed in terms of the concentration of the pollutants and $p \mathrm{H}$. The percentage of phosphates and metals removed was calculated according the following equation: \% removal $=\left[\left(\mathrm{C}_{0}-\mathrm{C}_{\mathrm{e}}\right) / \mathrm{C}_{0}\right] \mathrm{x} 100$, where $\mathrm{C}_{0}$ and $\mathrm{C}_{\mathrm{e}}$ are the initial and final phosphates concentration in solution $(\mathrm{mg} / \mathrm{L})$.

\section{Results and discussion}

\section{Characteristics}

The $p \mathrm{H}$ of the both red mud samples is alkaline; $\mathrm{RMH}$ has a higher $p \mathrm{H}$ (12.1) than $\mathrm{RM}(10.9)$. This is the result of transformations of some chemical species into oxides which by dissolution in water form hydroxides and give additional alkaline character RMH. Thermal sludge treatment did not lead to a significant increase the contact surface. There are not significant differences between the chemical compositions of the two red mud samples. The analysis highlight significant amounts of $\mathrm{Fe}, \mathrm{Al}, \mathrm{Si}, \mathrm{Na}, \mathrm{Ca}$ oxides (fig.4). Based on XRF results it can be seen that the red mud is rich in iron.
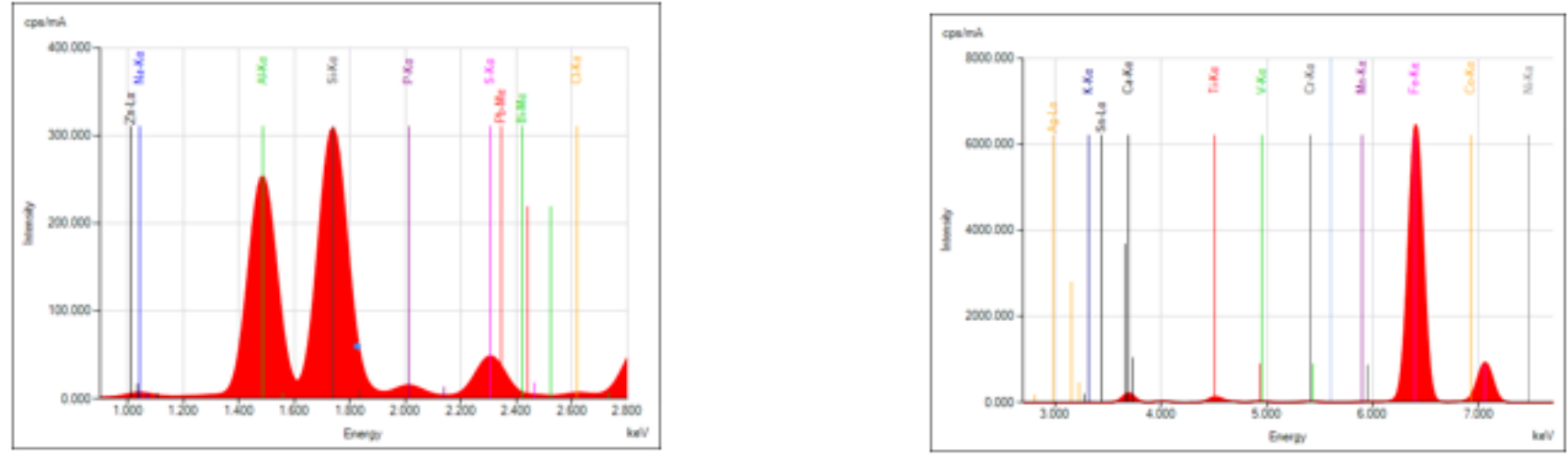

Fig.4. EDX spectrum of red mud

SEM analysis showed that both samples of red mud highlight relatively free microstructures and large porosities with dispersed particles. RMH has a more porous surface generated by the removal of moisture and water constituted from 
minerals (boehmite, gibbsite) due to calcite decomposition. At the surface of the RMH particles we can see structures that can be formed by oxides after calcination. Mainly $\mathrm{Fe}, \mathrm{Al}, \mathrm{Si}, \mathrm{Ti}, \mathrm{Na}$ is the reactive part of the red mud surface.

\section{Applications for phosphates removal from wastewaters}

The experimental research with paper making wastewaters and knitwear wastewater highlighted that the percentage removal of phosphate depend on the composition from wastewater (table 2). A wastewater with higher organic load and a significantly higher chlorine content indicated lower phosphates removal efficiency even at high doses of red mud used. The differences between phosphate removal efficiency are also due to thepH of the samples; a higher initial $p \mathrm{H}$ leads to high phosphate removal efficiency.

It is apparent that the phosphates removal efficiency increases with increasing the red mud dosage; at the beginning the sorption level of phosphates increases significantly.

The increase in phosphates removal with red mud adsorbent dosage is due to greater availability of adsorbent surface area and more active sites.

Table 2

THE INFLUENCE OF THE RED MUD TYPE AND DOSE TO THE PHOSPHATES REMOVAL EFFICIENCY

\begin{tabular}{|cccc|}
\hline The red mud type & $\begin{array}{c}\text { The red mud dose } \\
(\mathrm{g} / \mathrm{l})\end{array}$ & $\begin{array}{c}\text { The percentage removal of } \\
\text { phosphate from paper making } \\
\text { wastewater(\%) }\end{array}$ & $\begin{array}{c}\text { The percentage removal of } \\
\text { phosphate from knitwear } \\
\text { wastewater(\%) }\end{array}$ \\
\hline RM & 0.5 & 27.9 & 8.7 \\
\cline { 2 - 4 } & 1.5 & 90.8 & 72.9 \\
\hline RMH & 3 & 98.9 & 86.3 \\
& 0.5 & 51.4 & 5.4 \\
\hline & 1.5 & 90.5 & 63 \\
\hline
\end{tabular}

The experimental results for each of the tested wastewaters indicated that the type of red mud used (RM or RMH) did not significantly influence the phosphate removal efficiency; this is due to their composition (fig.5, fig.6). The maximum phosphates removal efficiency was at the higher dose red mud (RM). These observations are in agreement with the SEM analysis which showed that both samples of red mud have relatively free microstructures and large porosities with dispersed particles.

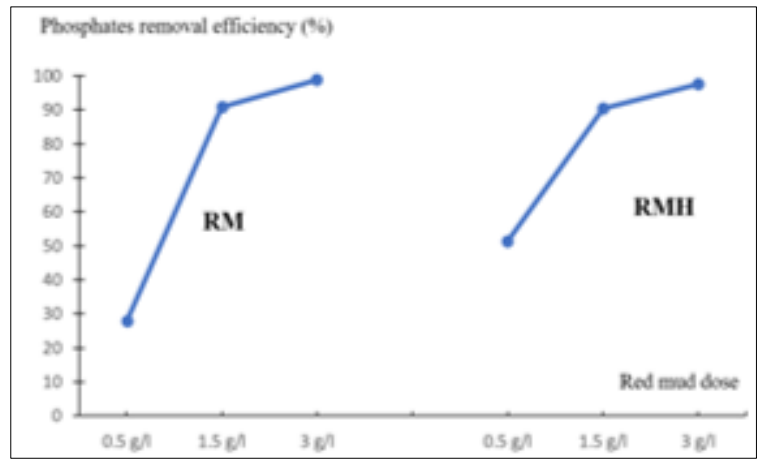

Fig.5. Effect of the type and dose red mud to the percentage removal of phosphate from paper making wastewater

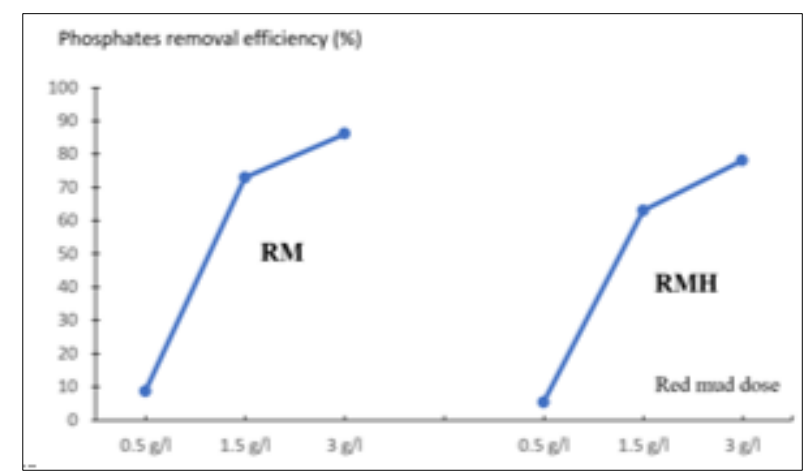

Fig.6. Effect of the type and dose red mud to the percentage removal of phosphate from the knitwear wastewater

\section{Applications for metals removal from mine water}

The result of the experiments with mine water using RM and RMH are presented in figure 7. The removal efficiencies of heavy metals (nickel, zinc, arsenic) is given. The metals removal efficiency are similarly for the red mud types used, to each red mud dose (e.g. for $1.5 \mathrm{~g} / \mathrm{L}$ red mud dosage, the nickel, zinc, arsenic removal efficiencies are $25 \%$, respectively $41 \%$ and $93 \%$ in case of RM while the nickel, zinc, arsenic removal efficiencies are $21 \%$, respectively $38 \%$ and $89 \%$ in case of RMH).

When the red mud concentration is high, concentration of surface hydroxyl groups is higher through surface site density. Increased surface hydroxyl group favor adsorption of metals (nickel, zinc). In arsenic case the removal efficiency shows high values (higher than 90\%) any dose of red mud used. 


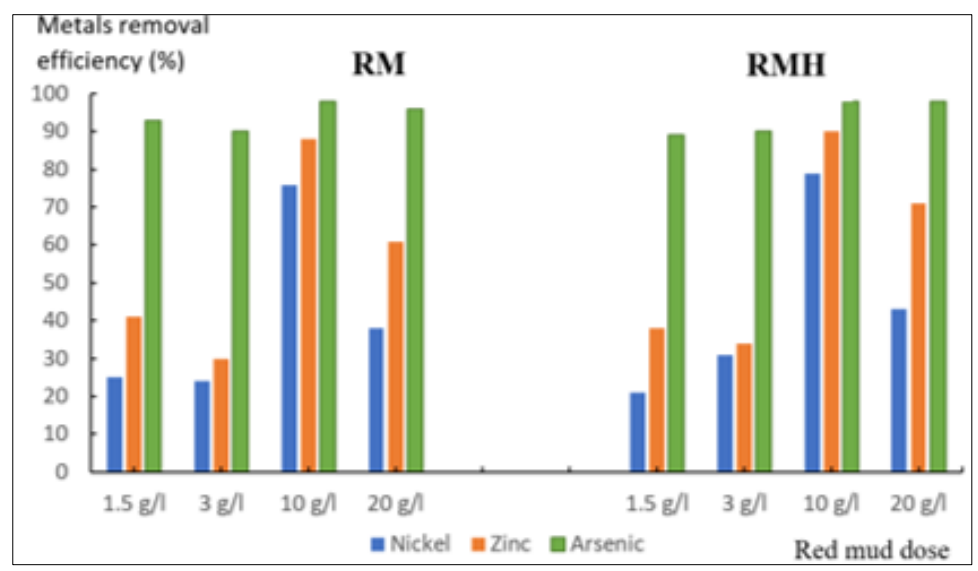

Fig.7. Effect of the type and dose red mud to the percentage removal of metals from mine wastewater

The figure 7 shows that the removal efficiencies increases in the following order Nickel-Zinc-Arsenic.

Experimental research has shown that concurrently with the removal of heavy metals from the water, the $p \mathrm{H}$ increases (table 3).

Table 3

THE EFFECT OF THE AMOUNT OF RED MUD USED ON THE FINAL $p$ H OF THE WATER

\begin{tabular}{|c|c|c|c|c|}
\hline Red mud & $1.5 \mathrm{~g} / \mathrm{L}$ & $3 \mathrm{~g} / \mathrm{L}$ & $10 \mathrm{~g} / \mathrm{L}$ & $20 \mathrm{~g} / \mathrm{L}$ \\
\hline & \multicolumn{4}{|c|}{ pH final } \\
\hline RM & 2.9 & 2.9 & 3.3 & 4.3 \\
\hline RMH & 3.0 & 3.0 & 3.5 & 4.4 \\
\hline
\end{tabular}

SEM images of red mud (RM and RMH) after the experiments with mine water revealed the presence of aggregates, microstructures in the form of crystals, which appeared on their surface upon contact with acidic water (fig.8, fig.9).

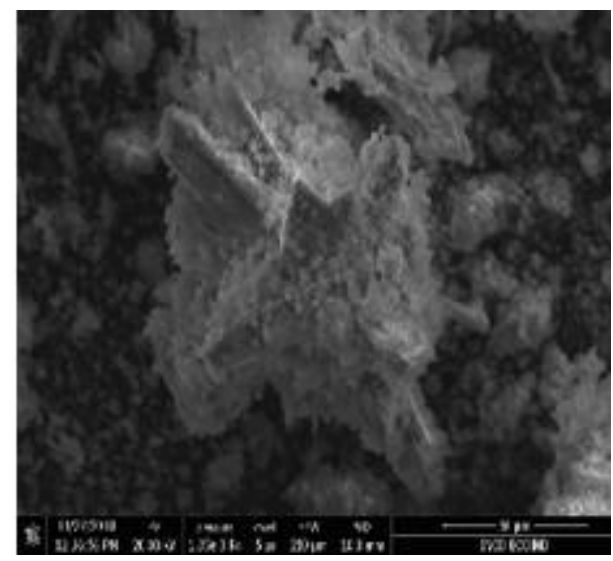

Fig.8. RM+mine water

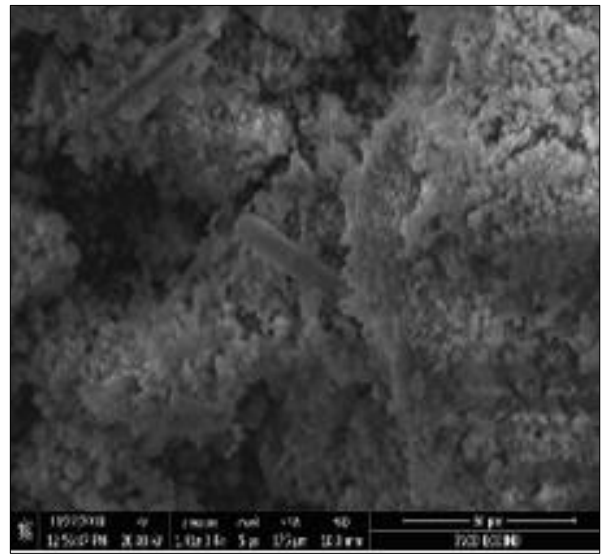

Fig.9.RMH+mine water

\section{Conclusions}

In this study, red mud (RM) and red mud after the heat treatment process (RMH), containing $\mathrm{Fe}, \mathrm{Al}, \mathrm{Si}, \mathrm{Ti}, \mathrm{Ca}, \mathrm{Na}$ oxides as major components was applied to treat different wastewaters: with phosphorous contents from paper making and knitwear production plants, respectively mine water with heavy metals from an abandoned mine, in batch system.

The type of red mud used (RM or RMH) did not significantly influence the phosphate removal efficiency; this is due to their composition. The increase in phosphates removal with red mud adsorbent dosage is due to greater availability of adsorbent surface area and more active sites.

The experiments with mine water using RM and RMH shows that removal efficiencies of heavy metals (nickel, zinc, arsenic) are similarly for the red mud types used, to each red mud dose.

Increased surface hydroxyl group to the red mud dose favor adsorption of metals (nickel, zinc). In arsenic case the removal efficiency shows high values (higher than 90\%) any dose of red mud used.

The removal efficiencies increases in the following order Nickel-Zinc-Arsenic. 
Experimental research has shown that concurrently with the removal of heavy metals from the water, the $p \mathrm{H}$ increases.

SEM images of red mud after the experiments with mine water showed that some aggregates, microstructures in the form of crystals, appeared on their surface upon contact with acidic water.

As the result of these researches, red mud proved to have positive influence on the removal the phosphates and heavy metals from wastewater, to reduce the pollution potential.

Aknowledgements: This work was supported by The Ministry of Research and Innovation through contract no. 20N/2019, Project code PN 19040401.

\section{References}

1. DURSUN S., GUCLU D., BAS M., Journal of International Environmental Application \& Science, 1, no.3-4, 2006, p.98-106

2. POULIN E., BLAIS J.F., MERCIER G., Hydrometallurgy, 92, no.1-2, 2008, p.16-25

3. SUSHIL S., BATRA V.S., Appl. Catal. B Environ., 81, 2008, p.64-77

4. ZHAO Y., WANG J., LUAN Z., PENG X., LIANG Z., SHI L., J. Hazard. Mater., 165, 2009, p.1193-1199

5.SHIVKUMAR S., PRAJAPATI, P.A., MOHAMED N.,V. M. TANGDE, Adv.Phys Chem., 2016, article ID 9075206, 9 pages, http://dx.doi.org/10.1155/2016/9075206

6. RAI S., WASEWAR K.L., LATAYE D.H., MUKHOPADDHYAY J., YOO C.K., Int. J. Environ. Sci. Technol., 10, 2013, p.305-314

7. KUMAR S., KUMAR R., BANDOPADHYAY A., Resour. Conserv. Recy., 48, no. 4, 2006, p.301-314

8. BUCUR, E., DANET, A., Rev. Chim. (Bucharest), 67, no. 4, 2016, p. 621.

9. PETRESCU, M., BUCUR, E., DIODIU, R., BRATU, M., SERBANESCU, A., BARBU, E.M., 20th International Symposium on The Environment and the Industry (SIMI), Bucharest, 2017, p. 213

10. BUCUR, E., IONITA, L., PETRESCU, M., J. Environ. Prot. Ecol., 11, no.3, 2010, p. 809.

11. YANJU L., RAVI N., HUI M., Geoderma, 163, 2011, p.1-12

12.SCHWARZ M., LALÍK V., Recent Researches in Metallurgical Engineering - From Extraction to Forming, IntechOpen , 2012, p.1-22

13. SGLAVO V.M., CAMPOSTRINI R., MAURINA S., CARTURAN G., MONAGHEDDU M., BUDRONI G., COCCO G., J. Eur. Ceram. Soc., 20,2000, p.235-244

14. SRIKANTH S., RAY A.K., BANDOPADHYAY A., RAVIKUMAR B., J. Am. Ceram. Soc., 88, 2005 , p.2396-2401.

15. VACHON P., TYAGI R.D., AUCLAIR J.C., WILKINSON K.J., Env. Sci. Tech., 28, 1994, p.26-30.

16. SNARS K.,GILKES R.J.,Appl. Clay Sci., 46, 2009, p.13-20

17. CHVEDOV D., OSTAP S., Le T., Colloids Surf.,A, 182, 2001, p.131-141

18. KALKANE, Eng. Geol.,87, 2006, p.220-229

19. BACIOIU I.G., STOICA L., CONSTANTIN C., STANESCU A.M., Water Air Soil Pollut., 228, 2017, p.298

20. WANG S., ANG H.M., TADE M.O., Chemosphere, 72, 2008, p.1621-1635

21. BABEL, S., KURNIAWAN, T. A. J. Hazard. Mater. 97, 2003, p.219-243

22. CRINI, G., Bioresour. Technol., 97, 2006, p.1061-1085

23. WANG, S.B., WU H.W., J. Hazard. Mater., 136, 2006, p.482-501

24. PICHINELLI B.C., GABRIEL DA SILVA M.S., TOMAZINI DA CONCEICAO F., MENEGARIO A.A., ANTUNES M.L.P., NAVARRO G.R.B., MORUZZI R.B. Water Air Soil Pollut., 228, 2017, p.24

25. PARAMGURUR. K., RATHP.C., MISRAV.N., Miner. Process. Extract. Metall. Rev, 26, 2005, p.1-29

26. LOPEZ E., SOTO B., ARIAS M., NUNEZ A., RUBINOS D., BARRAL M.T., Water Res.32, 1998, p.1314-1322

$\overline{\text { Manuscript received : 31.07.2019 }}$ 